\title{
Thoughts on Educational Issues of Chinese Minority Nationalities
}

\section{Jianhua Wang}

School of Sociology, Yunnan Minzu University, Kunming, Yunnan Province,650504, China

\begin{abstract}
Education is an important way to deliver high-quality talents to the country. The smooth progress of ethnic minority education is not only directly related to the country's cultural life, political structure and national culture, but also has an important impact on the country's long-term development. This article discusses the education of ethnic minorities from multiple angles, hoping to provide references for other educators while promoting the rapid development of ethnic minority education in my country.
\end{abstract}

Keywords: Educational Work; Problem Thinking; Educational Reform; Minority Education

My country has a vast territory and many ethnic groups, so how to cultivate more high-quality senior talents for the country through a strong promotion of the education of ethnic minorities has become a problem that needs to be solved by many educators. With the development of the times and the continuous improvement of my country's international status, the country is gradually moving towards a major technological and industrial country under the background of continuous economic development. This requires more high-quality talents who can become the backbone of the country's future development. The study of ethnic minority culture has a long history. It is necessary for educators to keep up with the development trend of the times and actively seek solutions to promote the better development of ethnic minority education, so as to enhance the effectiveness of ethnic minority education and deliver higher quality to the country. Talent.

\section{Difficulties faced by the orderly development of minority education}

\subsection{National Culture}

The formation of any nation cannot be separated from its own development culture. There are many ethnic minorities in my country, and the ceremonies, poems, customs and beliefs of different ethnic groups are quite different. Therefore, although a highly unified teaching system can effectively promote the smooth progress of education in Han ethnic areas, in the context of the diverse cultural development of ethnic minorities, sufficient attention has not been paid to the cultural characteristics of ethnic minorities, which has led to many ethnic minority regions. The content of the textbooks used is monotonous, and there is no teaching method that meets the individual development and learning needs of ethnic minority students. It simply teaches in accordance with the teaching methods in the Han area. This is not only detrimental to the orderly progress of education for ethnic minorities, but also in the process of ignoring their ethnic culture, it is difficult to produce a long-term education mechanism, and the overall educational work is seriously hindered.

\subsection{National script}

As the carrier of national development, writing can not only help people communicate effectively, but also serve as a means of cultural inheritance. However, the reality is that when many educators carry out education for ethnic minorities, Chinese is widely used in my country and is the main language of communication, so that students can better integrate into the social environment in the future development process. , Many regions choose to carry out bilingual

Copyright (C) 2020 Jianhua Wang

doi: 10.18282/le.v9i7.1506

This is an open-access article distributed under the terms of the Creative Commons Attribution Non-Commercial License

(http://creativecommons.org/licenses/by-nc/4.0/), which permits unrestricted non-commercial use, distribution, and reproduction in any medium, provided the original work is properly cited. 
education. This has caused many schools to place too much emphasis on the effectiveness of Chinese teaching, causing many students to focus their learning efforts on Chinese language learning, instead of ignoring the learning of their own national language and culture. This is not only not conducive to the inheritance of the national excellent culture, but also in the process of neglecting to promote the development of the national culture, it is easy to cause the decline of the minority languages and languages, which deserves people's attention.

\section{Specific ways to promote the orderly development of minority education}

\subsection{Support through policy guidelines}

The advent of the new era makes the country pay more attention to the education of ethnic minorities. In order to promote the high-quality development of educational activities, it is necessary to support policies and guidelines so that ethnic minority areas can earnestly implement the current education guidelines advocated by the state. And under the guidance of the scientific development concept, the people-oriented education viewpoint can be implemented, and then in the process of effectively reforming the education work currently facing obstacles, the high-quality development of the overall education reform work can be promoted. In addition, in the process of establishing ethnic minority schools, it is necessary to combine the current actual education situation, continuously integrate and expand educational resources, and strive to make their own educational level compatible with the development requirements of the times, and through the addition of a master team Training to improve the teaching level, teaching quality and professional skills of teachers, and ensure the rapid improvement of overall teaching quality and educational work. At the same time, the state should also continue to increase its investment in education in ethnic minority areas. Through the improvement and increase of infrastructure, teaching software and hardware can be continuously improved, and information technology education can be quickly introduced into ethnic minority areas. Create a more excellent educational environment while promoting the smooth progress of ethnic minority education.

\subsection{Carry out educational content centered on ethnic characteristics}

The unique language and culture, local customs, ethnic characters, and traditional culture of ethnic minority areas have become indispensable national treasures in the long history of my country's history and culture, and need to be actively inherited by ethnic minority students. Therefore, when carrying out educational work in ethnic minority areas, it is necessary to develop educational content with ethnic characteristics as the core, so as to establish correct values in the process of helping students learn better knowledge. This requires teachers to make reasonable innovations in teaching content in accordance with the continuous changes and development of the times when conducting teaching activities. At the same time, they should take national characteristics as the core, so that the teaching content can grasp the national characteristics, so as to better meet the minority characteristics. In the process of individualized development, language environment and speculative consciousness of ethnic students, the smooth completion of education is guaranteed, and the goal of inheriting ethnic minority culture is achieved. In addition, in minority areas, in addition to paying attention to bilingual education, it should also be combined with the continuous change and development of society, and be able to introduce English into the education of ethnic minorities. Through simultaneous trilingual teaching, students should be able to meet social development Literacy, and grow into high-quality talents that the country needs.

\section{Concluding remarks}

All in all, if we want to advance the country's long-term development in the tide of the continuous development of the times, people need to pay attention to the current difficulties faced by ethnic minority education and actively seek solutions. This will not only effectively cultivate more high-quality talents for the country, but also promote better development conditions for ethnic minority areas while inheriting ethnic minority cultures. With the joint efforts of all sectors of society, the education of ethnic minorities It can achieve more vigorous development while meeting the development requirements of the times. 


\section{References}

1. Fu Rongwen, Zeng Jiayan. Foreign Language Education Planning in Ethnic Minority Regions: Policy Content and Planning Strategy__ Based on the Investigation of Basic Education in Minority Concentrated Areas in Guizhou Province[J]. Ethnic Education Research, 2020, 31(04) :149-155.

2. Fang Chao, Huang Bin. Estimation and Analysis of the Rate of Return to College Education of China's Minority Labor Force in the Economic Transition Period__Also Comment on the Impact of Enrollment Expansion Policy on Income Gap [J]. Ethnic Education Research, 2020, 31(04): 84 -94.

3. Jiang Yan, Bi Dong. Investigation and Research on the Educational Status of Left-behind Children in Ethnic Minority Areas__ Taking H Township, Chuxiong Yi Autonomous Prefecture, Yunnan Province as an Example [J]. Journal of Yunnan Agricultural University (Social Sciences), 2020, 14(04) :54-59. 